\title{
PARADISE LOST: CONTRACTING AWAY IMMUNITY UNDER THE INDIANA TORT CLAIMS ACT
}

\author{
TYLER JONES ${ }^{*}$
}

\section{INTRODUCTION}

Death is not what comes to mind when one speaks of going to the Fair-elephant ears, the world's largest pigs, tractor pulls, and so much more . . . but not death. August 13, 2011 was supposed to be another fun-filled day at the Indiana State Fair. Unfortunately, however, the sky blackened and the winds began to stir. Nature had other plans. ${ }^{1}$

The country band Sugarland had been scheduled to play at approximately 8:45 PM but, due to the oncoming storm and the band's tight schedule, ${ }^{2}$ the decision was made to try to start the concert earlier. ${ }^{3}$ As the skies grew more ominous, Sugarland would not take the stage; instead, winds between sixty and seventy miles per hour roared through the open air venue. ${ }^{4}$ The stage buckled, killing seven people and injuring several more. ${ }^{5}$

Needless to say, an investigation and, eventually, litigation ensued. Several Fair officials would either be terminated or enter early retirement as a result of their role. ${ }^{6}$ An investigation determined that the stage, which was owned by MidAmerica Sound ("Mid-America"), was structurally deficient because it was unable to withstand gusts of up to sixty-eight miles per hour, the industry standard. ${ }^{7}$ Victims and survivors filed numerous lawsuits against the Indiana State

* J.D. Candidate, 2017, Indiana University Robert H. McKinney School of Law; B.A. 2013, Indiana University - Bloomington. I would like to thank Professor James P. Nehf for his help in the development and editing of this paper; I would like to thank Dean Andrew R. Klein for his encouragement throughout this process; and I would also like to thank my parents and God for their continual guidance and support.

1. John Tuohy, Rewind: State Fair Stage Collapse: Whose Call Was It?, InDianAPOLIS STAR (Apr. 11,2015, 11:38 AM), http://www.indystar.com/story/news/2015/04/11/state-fair-stagecollapse/25629299/ [http://perma.cc/JR6U-WAX5].

2. Sugarland Sued over Stage Collapse, USA TODAY (Nov. 23, 2011, 12:30 PM), http://usatoday30.usatoday.com/life/music/news/story/2011-11-23/sugarland-stage-collapselawsuit/51361512/1 [http://perma.cc/G3ZK-R3GT]. It is suggested that Sugarland declined to delay the show because they could potentially forfeit all or part of the $\$ 300,500$ admission fees.

3. Tuohy, supra note 1. It is a matter of debate exactly who chose to continue the concert, as opposed to evacuating the area. Id. The Fair Commission blamed the band and their promoters, who had a concert the next day and were unwilling to cancel the show. Id. The band suggested that the Fair Commission only asked them not to play but did not tell them they could not. Id.

4. Id.

5. Charles Wilson, Indiana Fair Makes Management Changes After Collapse, HuFFINGTON Post (May 10, 2012, 7:49 PM), http://www.huffingtonpost.com/2012/05/11/ind-fair-makesmanagement_n_1508030.html [http://perma.cc/F4JA-NLWL].

6. $I d$.

7. Rick Callahan, Indiana Stage That Collapsed During State Fair Did Not Meet Building 
Fair Commission (the "State") and Mid-America. However, the Indiana Tort Claims Act ("ITCA"), Indiana Code sections 34-13-3-0.1 to -25, imposes a statutory cap on tort liability. As a result, the State could only claim $\$ 5$ million worth of damages at most. ${ }^{8}$ Despite this, most ended up settling with the State, though a few labored on, ultimately failing via a constitutional challenge against the ITCA. ${ }^{9}$

With the closing of its direct liability, the State breathed a heavy sigh and contented itself with the fact that, although it had just shelled out $\$ 11$ million via settlement agreements ${ }^{10}$ it would not get any worse. Unfortunately, for the State, it got worse. As litigation started among the victims and Mid-America Sound, the company that supplied the stage, Mid-America contacted the State and demanded that, pursuant to an express agreement, ${ }^{11}$ the State defend it and hold it harmless for any liability incurred as a result of the litigation. ${ }^{12}$ As one might expect, the State refused. ${ }^{13}$

Mid-America filed third-party and cross-claims against the State to compel indemnification. ${ }^{14}$ In response, the State filed for and was granted a motion for summary judgment by the trial court. ${ }^{15}$ The Indiana Court of Appeals disagreed and reversed the trial court in a 2-1 decision. ${ }^{16}$ A side from the main thrust of arguments addressing the applicability and unconscionability of the clause, the State argued that the State Fair Commission, as a State entity, could not enter into such an agreement because it was barred by the ITCA. ${ }^{17}$ The court of appeals first noted that the State Fair Commission had been given broad authority to enter into

Code: Report, Huffington Post (Apr. 12, 2012, 1:20 PM), http://www.huffingtonpost. com/2012/04/12/indiana-stage-that-collap_n_1421186.html [http://perma.cc/D77K-JT77].

8. IND. CODE $\S 34-13-3-4$ (2016). In response to public outcry, this cap was later raised by $\$ 6$ million for the purpose of paying those who settled with the State. See id. §§ 34-13-8-5, -6.

9. See VanDam Estate v. Mid-Am. Sound, 25 N.E.3d 165 (Ind. Ct. App. 2015), trans. denied, 34 N.E.3d 250 (Ind. 2015) (holding unanimously that the ITCA damages cap does not violate the Open Courts Clause or the Equal Privileges Clause of the Indiana Constitution).

10. Troy Kehoe, Proposed Settlement Filed in State Fair Stage Collapse Lawsuit, WisH-TV (Sept. 9, 2014, 6:17 PM), http://wishtv.com/2014/09/09/proposed-settlement-filed-in-state-fairstage-collapse-lawsuit/ [https://perma.cc/8JC6-ZHQC].

11. Polet v. Mid-Am. Sound (In re Ind. State Fair Litig.), 28 N.E.3d 333, 336 (Ind. Ct. App. 2015), rev'd sub nom. Mid-Am. Sound v. Ind. State Fair Comm'n, 49 N.E.3d 545 (Ind. 2016). There was considerable disagreement between the parties whether this was an agreement at all and much of the case is dedicated to addressing issues of unconscionability and other related contractual issues not relevant to this discussion. See generally id.

12. Id. at 337.

13. Id. Besides the policy arguments regarding the ITCA and sovereignty, the State argued that the agreement was unconscionable or at least unenforceable for a number of reasons. See generally id.

14. Id.

15. Id.

16. Id. at 343 .

17. Id. at 342 . 
contracts $^{18}$ and that nothing expressly forbade them from indemnifying third parties. ${ }^{19}$ Next, the court stated that it understood an indemnification claim, even for another's tort, as a contractual question because the source of that duty was a contract. ${ }^{20}$ Thus, construing the ITCA strictly, ${ }^{21}$ the court found that the ITCA did not apply because the State had validly entered into a contract and that contract was not subject to the limitations of the ITCA, which only governed tort actions. ${ }^{22}$

In a firmly worded dissent, Chief Judge Vaidik criticized the majority's opinion for not recognizing a "tort in contract's clothing" and the fact that this type of situation was implicitly accounted for in the ITCA. ${ }^{23}$ Specifically, the dissent pointed to Indiana Code section 34-13-3-3(10) ${ }^{24}$ and the Indiana Supreme Court's decision in Hinshaw v. Board of Commissioners of Jay County, ${ }^{25}$ The court determined this scenario was much like Hinshaw, which denied an attempt to extend "vicarious liability on governmental entities and employees by reason of conduct of third parties. ${ }^{, 26}$ Echoing the State's arguments, Chief Judge Vaidik stressed that allowing express indemnity in this situation would undermine "the legislature's critical role in protecting $[S]$ tate funds from exposure to unlimited liability," one of the main purposes for the ITCA. ${ }^{27}$

Although the Indiana Supreme Court would eventually reverse the court of appeals, it reversed on grounds relating to the enforceability of the agreement under the specific facts of the case; namely, that the State entered into a retroactive indemnity agreement, implicitly. ${ }^{28}$ The Indiana Supreme Court

18. IND. CoDE $§ 15-13-3-4$ (2016) (stating, "The commission may ... [e]nter into contracts related to the commission's powers and duties under this article.").

19. In re Ind. State Fair Litig., 28 N.E.3d at 343.

20. Id.

21. See City of Indianapolis v. Buschman, 988 N.E.2d 791, 794 (Ind. 2013).

22. In re Ind. State Fair Litig., 28 N.E.3d at 343 (citing JPMCC 2006-CIBC14 Eads Parkway, LLC v. DBL Axel, LLC, 977 N.E.2d 354, 364 (Ind. Ct. App. 2012)) (stating a party may not "restyle [a] breach-of-contract claim as a tort claim simply to avoid liability").

23. Id. at 344 .

24. IND. CODE $\S 34-13-3-3$ (2016) (“A governmental entity or an employee acting within the scope of the employee's employment is not liable if a loss results from ... [ $t$ ] he act or omission of anyone other than the governmental entity or the governmental entity's employee.").

25. 611 N.E.2d 637, 640 (Ind. 1993).

26. In re Ind. State Fair Litig., 28 N.E.3d at 345.

27. Id. Besides this reason, other Courts have emphasized another critical function for the ITCA. See Board of Comm'rs v. King, 481 N.E.2d 1327, 1330 (Ind. Ct. App. 1985) (finding that " $[\mathrm{t}]$ he policy underlying the [ITCA] is to protect public officials in the performance of their duties by preventing harassment by threats of civil litigation over decisions they make within the scope of their position"); accord Ellis v. City of Martinsville, 940 N.E.2d 1197, 1207 (Ind. Ct. App. 2011) (same); Fowler v. Brewer, 773 N.E.2d 858, 861-62 (Ind. Ct. App. 2002) (same).

28. Mid-Am. Sound Corp. v. Ind. State Fair Comm'n (In re Ind. State Fair Litig.), 49 N.E.3d 545 (Ind. 2016). As will be discussed, indemnity provisions are disfavored and courts require a higher standard to enforce them, as compared to normal contracts. The court essentially found that 
declined to comment on anything related to the issue raised above; specifically, whether the ITCA would be subverted by allowing the State to expressly indemnify a private third-party. ${ }^{29}$

This Note will explore the history behind both the ITCA and contractual indemnity and the potential implications of giving the State this right. The purpose of this Note, however, is to advocate for the position that allowing the State to expressly indemnify a private party would not undermine the language or purpose of the ITCA because there are critical distinctions between them, based on the different liabilities, motivations, and natures of the claims themselves. Consequentially, this Note contends that any restraint on this ability would prove to be an unjustified restraint on the State's contracting powers and a grave, equitable failing with regard to the contractual expectations of the private party and the sanctity of contracts in general.

This Note is divided into five parts and each part into relevant sections. Part I will detail a broad history of the development of sovereign immunity and indemnification, with a focus at the end on Indiana's treatment of the doctrines. Parts II through IV will each address the arguments for permitting State indemnification. Parts II and III assume that the relevant state agency has the power to enter into indemnity contracts while Part IV does not. Part V will then briefly discuss the implications and potential motivations for allowing the State this added flexibility.

\section{BACKGROUND}

\section{A. Sovereign Immunity: History-From Rome to Indianapolis}

The contentious nature that sovereign immunity holds today was captured by Justice Stevens when he noted (perhaps with a twinge of sarcasm), "[T]he doctrine of sovereign immunity is nothing but a judge-made rule that is sometimes favored and sometimes disfavored." ${ }^{, 30}$ Most simply defined, sovereign

because retroactive application of an insurance or indemnity agreement, where the loss has already occurred, would be a "fool's bargain," the court would only enforce such a burden if it was expressly agreed on; the court would not enforce such an agreement implicitly, e.g., by course of conduct. $I d$. at 549-50. The court then characterized Mid-America's purported indemnification clause as retroactive and did not find any evidence of an express agreement. Id. at 550-53. Course of conduct or course of dealing, by itself, was insufficient to validate the agreement. $I d$. at 552-54.

29. Id. at 553.

[W] express no opinion on whether the Commission is a governmental entity with immunity under the Indiana Tort Claims Act (ITCA), IND. CODE [\$] 34-13-3; whether indemnity for another party's negligence is a tort or contract-based liability for ITCA purposes; or whether the invoices' indemnity language is void against public policy.

Id.

30. United States v. Nordic Vill. Inc., 503 U.S. 30, 42 (1992) (Stevens, J., dissenting), superseded by statute, 11 U.S.C. $§ 106$, as recognized in In re Equip. Acquisition Res., Inc., 742 F.3d 743 (7th Cir. 2014). 
immunity is "[a] government's immunity from being sued in its own courts without its consent." ${ }^{31}$ The modern doctrine is a transmutation from the original rule which, put simply, held "the King can do no wrong." 32 Because of these origins, which are seemingly intolerable to a democratic form of government, ${ }^{33}$ the doctrine has been heavily scrutinized and abrogated by virtue of the Federal Tort Claims Act (1946) and the corresponding Tort Claims Acts of the several states, though some commentators stress its persisting influence and importance. ${ }^{34}$ Regardless of its vitality today, the doctrine's continued longevity is a testament to its roots in almost a millennium of common and civil law, spanning numerous peoples and cultures. ${ }^{35}$

Not surprisingly, the origins of the doctrine are as contentious as the doctrine itself. Certainly, it is hard to imagine that a mere peasant might have been able to entertain a claim against a God-king or emperor in some of the ancient, mighty empires of the past, like Persia, Egypt, or China. Furthermore, it is difficult to link any of these practices to the Western Legal Tradition. The first seeds of the modern doctrine debatably surfaced in the late Roman era under the civil code of Eastern Roman Emperor Justinian I (527 C.E. - 565 C.E.); ${ }^{36}$ though some commentators have largely dismissed this notion. ${ }^{37}$ Even if these were the seeds of the doctrine, it is unclear to what extent medieval jurists borrowed from this premise. $^{38}$

The first definite manifestation of sovereign immunity arose in the midtwelfth century in the Holy Roman Empire, ${ }^{39}$ under the reign of Emperor

31. Immunity, BLACK's LAW DictionARY (10th ed. 2014).

32. Mark C. Niles, "Nothing but Mischief": The Federal Tort Claims Act and the Scope of Discretionary Immunity, 54 ADMIN. L. REV. 1275, 1283 (2002).

33. Fred O. Smith Jr., Awakening the People's Giant: Sovereign Immunity and the Constitution's Republican Commitment, 80 FordHAM L. REV. 1941, 1941-42 (2012).

34. See generally Katherine Florey, Sovereign Immunity's Penumbras: Common Law, Accident, and Policy in the Development of Sovereign Immunity Doctrine, 43 WAKE Forest L. REV. 765 (2008).

35. James E. Pfander \& Jonathan L. Hunt, Public Wrongs and Private Bills: Indemnification and Government Accountability in the Early Republic, 85 N.Y.U. L. REV. 1862, 1918 (2010).

36. Kenneth Pennington, The Prince and the Law: Sovereignty and Rights in the Western Legal Tradition 76-80 (Univ. Cal. Press 1993).

37. Compare George W. Pugh, Historical Approach to the Doctrine of Sovereign Immunity, 13 LA. L. REv. (1953), available at http://digitalcommons.law.lsu.edu/lalrev/vol13/iss3/5 [http://perma.cc/N6CE-SXV5], with PENNINGTON, supra note 36.

38. Pennington, supra note 36.

39. Id. at 8-37, 119-32; Joachim Whaley, Germany and the Holy Roman Empire: Volume I: MaXimilian I to the Peace of Westphalia, 1493-1648, at 17-20 (Oxford Univ. Press 2012). Not to be confused with the Roman Empire, the Holy Roman Empire was, generally, a loose confederation of various central European political entities under the personage of the Holy Roman Emperor. Peter H. Wilson, The Holy Roman Empire, 66 History TODAY (Apr. 2016), http://www.historytoday.com/peter-h-wilson/holy-roman-empire [https://perma.cc/J2ML-J8WT]. The Empire, although lasting nominally until the Nineteenth Century C.E., is usually associated 
Frederick I (Barbarossa) (1155 C.E. - 1190 C.E.). ${ }^{40}$ Citing scripture ${ }^{41}$ and debatably Roman code, Barbarossa's jurists theorized that his power was from a divine right and that his will was the positive law of the land. ${ }^{42}$ Because the Emperor's will was his empire's law, ${ }^{43}$ it was theoretically impossible for his person or his empire to commit a crime; hence the popular simplification: "the King can do no wrong." ${ }^{44}$

Although it is unclear exactly how the doctrine migrated, its appeal to feudal monarchs is obvious, and it spread throughout Western Europe, including England. ${ }^{45}$ Correspondences between then King Henry II (1154 C.E. -1189 C.E.) and Emperor Barbarossa suggest that the idea may have spread as early as the late twelfth century; ${ }^{46}$ however, it is certain that the concept was incorporated into the common law no later than 1268, during the reign of King Henry III (1216 C.E. - 1272 C.E.). ${ }^{47}$ This early English conceptualization largely encapsulated the traditional justifications, while also developing a jurisdictional element. ${ }^{48}$

By the seventeenth century and the initial colonization of America, the doctrine, while facially intact, waned, as a consequence of the growing power of Parliament. ${ }^{49}$ More precisely, the doctrine had become nothing more than an academic exercise; most people truly wronged by the State had the option, though not necessarily the means, to seek relief as a matter of course through various petitions or writs. ${ }^{50}$ In his law review article, Harvard instructor, Professor Jaffe, emphasized that despite the availability of these writs, the average person had little chance of properly complying with the procedural rigors they demanded, effectively abrogating state liability in practice. ${ }^{51}$

With the onset of the American Revolution it was understandably difficult

with the Middle Ages and the Renaissance. Id. The reference to Rome was derived from the claim that the emperors inherited their authority from the emperors of Rome. WHALEY, supra, at 17.

40. Pennington, supra note 36, at 8-37, 119-32. After Barbarossa conquered much of Tuscany, he phrased a question to four jurists from the famous law school at Bologna (est. 1088), namely, "[W] hat was the Emperor's status in relation to the law?" Id.

41. See, e.g., Romans 13:1-7 (New King James).

42. Pennington, supra note 36.

43. Contemporary scholarship suggests that the jurists also argued that the Emperor would be subject to the will of God and "natural law." Id.

44. Id.

45. Id. at 17 .

46. Id.

47. Niles, supra note 32 , at $1282-83$.

48. Id. at $1282-84$.

49. Id. at 1285 .

50. Louis L. Jaffe, Suits Against Governments and Officers: Sovereign Immunity, 77 HARV. L. REV. 1, 1, 6-8, 18-20 (1963). Relief as a matter of course was a specific procedure for seeking damages caused by the state. Professor Jaffe described it as being a "cumbersome procedural restriction."

51. Id. at 18-19. 
to justify a doctrine based on the divine right of kings, ${ }^{52}$ though the new nation inherited the idea of sovereign immunity by virtue of its common legal ancestry with England. ${ }^{53}$ In addition to this theoretical conundrum, numerous citizens and merchants also brought claims against the various State and Federal governments to pay bills, contracts loans, damages, and other causes of actions arising out of the Revolution. ${ }^{54}$

To resolve their dilemma, both theoretical and practical, American leaders and thinkers began to claim that, though feudal in origin, sovereign immunity was actually derived from the very nature of sovereignt ${ }^{55}$ - derived from the socalled "law of nations." ${ }^{56}$ The American version developed its own eccentricities, however. First, the American version omitted the various English petitions and writs which had allowed limited access to bring a claim, callusing the doctrine in form and substance..$^{57}$ Theoretical justifications aside, the "prime cause [of this substantive hardening] was the powerful resistance of the states to being sued on their debts [from the Revolution]. ${ }^{" 58}$ Second, the American version developed the idea of the "dual-sovereign," that the States and the Federal government simultaneously held immunity from their citizens and from each other. ${ }^{59}$ By the late nineteenth century, as a natural consequence of the academic exercise of the "dual-sovereign," States eventually had their own legal sovereign immunity recognized by the Federal government. ${ }^{60}$

52. See Chisholm v. Georgia, 2 U.S. (2 Dall.) 419, 471-72 (1793) ("[England] considers the Prince as the Sovereign ... [and] contemplates him as being the fountain of honor and authority; ... it is easy to perceive that such a sovereign could not be amenable to a Court of Justice . . . It was of necessity, therefore, that [this immunity] became incompatible [with the Revolution]."), superseded by constitutional amendment, U.S. CONST. amend. XI., as recognized in Va. Office for Prot. \& Advocacy v. Stewart, 563 U.S. 247 (2011).

53. Ralph Brubaker, Of State Sovereign Immunity and Prospective Remedies: The Bankruptcy Discharge as Statutory Ex Parte Young Relief, 76 AM. BANKR. L.J. 461, 473-75 (2002).

54. Jaffe, supra note 50, at 19.

55. See, e.g., The Federalist No. 81, at 486-87 (Alexander Hamilton) (Clinton Rossiter ed., 1961) ("It is inherent in the nature of sovereignty not to be amenable to the suit of an individual without its consent. This is the general sense, and the general practice of mankind; and the exemption, as one of the attributes of sovereignty, is now enjoyed by the government of every State in the Union. Unless, therefore, there is a surrender of this immunity in the plan of the convention, it will remain with the States, and the danger intimated must be merely ideal.").

56. Alden v. Me., 527 U.S. 706, 728-29, (1999).

57. Jaffe, supra note 50, at 18-20.

58. Id. at 19; see also Campbell v. State, 284 N.E.2d 733, 734 (Ind. 1972), superseded by statute, Indiana Tort Claims Act, IND. CoDE $§$ 34-13-3-0.1 to -25 (2016), as recognized in Cantrell v. Morris, 849 N.E.2d 488, 495 (Ind. 2006).

59. Brubaker, supra note 53.

60. Hans v. Louisiana, 134 U.S. 1, 20-21 (1890); see also Seminole Tribe v. Florida, 517 U.S. 44, 53-55 (1996), superseded by statute in part, Uniform Services Employment and Reemployment Rights Act of 1994, 38 U.S.C. $\S \S 4301-4335$, as recognized in Huff v. Office of the Sheriff, No. 7:13CV00257, 2013 U.S. Dist. LEXIS 161954 (W.D.V. Nov. 13, 2013); Principality of Monaco 
Indiana kept with the tradition of the earlier States and adopted traditional common law sovereign immunity under the "hierarchy of laws." ${ }^{61}$ This did not change with the ratification of Indiana's second constitution in $1851 .^{62}$ By 1889 , the General Assembly passed the first legislation allowing individuals to bring a contract claim against the State. ${ }^{63}$ Over the course of a century, Indiana courts would chip-away at the protections of common law sovereign immunity ${ }^{64}$ until 1972 when a unanimous Indiana Supreme Court in Campbell v. State essentially destroyed the last vestiges of common law sovereign immunity, ${ }^{65}$ except for a few specific instances. ${ }^{66}$

\section{B. Sovereign Immunity: Modern Application}

As a direct response to Campbell v. State, in 1974 the Indiana General Assembly passed the Indiana Tort Claims Act (ITCA) ${ }^{67}$ Codified at Indiana Code Section 34-13-3 (2013), "The Indiana Tort Claims Act ("ITCA") governs tort claims against governmental entities and public employees ... [and provides that] governmental entities can be subjected to liability for tortious conduct unless the conduct is within an immunity granted by Section [three] of the ITCA." ${ }^{68}$ Section

v. Mississippi, 292 U.S. 313, 321-24 (1934).

61. St. John Town Bd. v. Lambert, 725 N.E.2d 507, 512, n.4 (Ind. Ct. App. 2000); see also IND. CoDE $\S 1-1-2-1$ (1852). The 1816 Constitution also permitted the General Assembly to pass an act allowing a suit against the State to proceed. St. John Town Bd., 725 N.E.2d at 512 n.4.

62. Id. Like the 1816 Constitution, the 1851 Constitution permitted the Legislature to allow claims against the State. $I d$.

63. Id.

64. See Perkins v. State, 251 N.E.2d 30, 35 (Ind. 1969) (retracting immunity from the State for proprietary functions); Klepinger v. Bd. of Comm. Miami, 239 N.E.2d 160, 177-78 (Ind. Ct. App. 1968) (retracting immunity from counties for most functions); Brinkman v. Indianapolis, 231 N.E.2d 169, 173 (Ind. Ct. App. 1967) (retracting immunity from municipalities for most functions); Flowers v. Bd. of Comm'rs of Cnty. of Vanderburgh, 168 N.E.2d 224, 225 (Ind. 1960) (retracting immunity from counties for proprietary functions); City of Goshen v. Myers, 21 N.E. 657 (Ind. 1889) (retracting immunity from municipalities for proprietary functions), all superseded by statute, Indiana Tort Claims Act, IND. CoDE $§ \S 34-13-3-0.1$ to -25 (2016), as recognized in Cantrell v. Morris, 849 N.E.2d 488, 495 (Ind. 2006).

65. 284 N.E.2d 733, 734-35 (Ind. 1972), superseded by statute, Indiana Tort Claims Act, IND. CODE $\S \S 34-13-3-0.1$ to -25 (2016), as recognized in Cantrell, 849 N.E.2d at 495 . The early cases that shrank governmental immunity did so on the basis of differentiating between "proprietary" and "governmental" functions; the former functions not being immune and the latter being immune. In Campbell, the Indiana Supreme Court admitted that the terms were never well defined and had no bright-line meanings. 284 N.E.2d at 735.

66. Id. at 738-39 (holding that sovereign immunity was inapplicable to the State except in instances of claims for crime prevention, appointments to public office, and judicial decisionmaking).

67. Veolia Water Indianapolis, LLC v. Nat'1 Trust Ins. Co., 3 N.E.3d 1, 5 (Ind. 2014).

68. Gary Cmty. Sch. Corp. v. Boyd, 890 N.E.2d 794, 799 (Ind. Ct. App. 2008). 
three of the ITCA lists all tort immunities available to the State and its employees. ${ }^{69}$ This section - as a whole- has been upheld as constitutional. ${ }^{70}$

As suggested by Campbell and the case law leading up to it, courts generally disfavor immunity and strictly construe the ITCA against limitations on a petitioner's right to bring suit. ${ }^{71}$ In general, the party seeking immunity bears the burden of demonstrating that its actions fall under the protections of the ITCA. ${ }^{72}$ Though the vestiges of the common law approach are still available, because of a policy of acquiescence to the legislature, these options cannot be resorted to unless the government defendant would not be immune under the ITCA. ${ }^{73}$

\section{Contractual Indemnity: History-From Rome to Indianapolis}

Indemnity is "[a] duty to make good any . . . liability incurred by another."74 Additionally, indemnification is " $[\mathrm{t}] \mathrm{he}$ action of compensating for loss or damage sustained. ${ }^{, 75}$ Indemnity, in one form or another, ${ }^{76}$ originates at least as far back as the late Roman Empire, with one man acting as a surety who had the duty to hold another harmless to a creditor if a debt was not paid. ${ }^{77}$ Arguably, indemnity agreements have existed informally just as long as there have existed sureties, because inherent in the idea of a surety, is an agreement to reimburse a third party for another's wrongs or failings in exchange for compensation of some sort. ${ }^{78}$

Regardless of its origins, English law adopted the practice. ${ }^{79}$ As part of the American legal system's common ancestry, agreements to act as another's surety or to indemnify another have been recognized since the beginning of the nation and suits involving such agreements or those lawsuits filed to enforce a private agreement were common ${ }^{80}$ However, these were not the equivalent to modern hold-harmless agreements or other agreements to indemnify another's negligence, which would not become popular until the late 1960s and the Supreme Court's

69. IND. CODE $\S 34-13-3-3$ (2013) ("A governmental entity or an employee acting within the scope of the employee's employment is not liable if a loss results from the following ....”).

70. Krueger v. Bailey, 406 N.E.2d 665, 670 (Ind. Ct. App. 1980).

71. City of Indianapolis v. Buschman, 988 N.E.2d 791, 794 (Ind. 2013).

72. Veolia Water Indianapolis, LLC v. Nat'l Trust Ins. Co., 3 N.E.3d 1, 5 (Ind. 2014).

73. Benton v. City of Oakland City, 721 N.E.2d 224, 232 (Ind. 1999).

74. Indemnity, Black's Law Dictionary (10th ed. 2014).

75. Indemnification, BLACK'S LAW Dictionary (10th ed. 2014).

76. Fox v. Kroeger, 35 S.W.2d 679, 680-81 (Tex. 1931). Besides contractual indemnity, the idea of "equitable indemnity," where a tortfeasor allocates liability to another absent an agreement, came into formal existence in England, though England's rule was drawn from Roman code. Id.

77. Id. at 681 .

78. The Surety's Indemnity Agreement: Law and Practice 11 (Marilyn Klinger et al. eds., 2nd ed. 2008); see also Fox, 35 S.W.2d at 681.

79. Fox, 35 S.W.2d at $680-81$.

80. See, e.g., Ayer v. Hutchins, 4 Mass. 370 (1808); Hamaker v. Eberley, 2 Binn. 506 (Pa. 1810); Hoffman v. Brown, 6 N.J.L. 429 (1798); Stewart v. Eden, 2 Cai. 150 (N.Y. Sup. Ct. 1804); Steele v. Boyd, 33 Va. 547 (1835). 
United States v. Seckinger decision. ${ }^{81}$ More often than not, these were bond agreements or agreements to act as another's surety on a promissory note. ${ }^{82}$

Under certain circumstances, a private citizen might also have sought indemnity from the government. The late English and early American practice involved the submission of private bills to Parliament or Congress, incurred because of government action. ${ }^{83}$ These bills would then be voted on and funds dispensed, if necessary ${ }^{84}$ However, although Congress allowed private entities to sue the government on these bills, they were not considered contractual. ${ }^{85}$

Indemnity was also present at Indiana's genesis (1816), but, like in other states, indemnity agreements came almost exclusively in the form of bond or insurance agreements; a far cry from the hold-harmless agreements present in many contracts today. ${ }^{86}$ Additionally, within a few years of Indiana becoming a state, cases dealing with common law indemnity began to arise, particularly in a government context. ${ }^{87}$ However, perhaps as a direct nod to Seckinger, the Indiana Supreme Court in Weaver v. American Oil Company condoned express indemnification for another's negligence if the indemnitor entered the agreement "willingly" and "knowingly." Though Weaver was not the first Indiana case to at least suggest that such agreements were enforceable, ${ }^{89}$ Weaver marks the first time a court utilized Indiana's modern standard. ${ }^{90}$

\section{Contractual Indemnity: Application and Modern Approach}

To enter into a contract to indemnify another party, one must do so "willingly" and "knowingly," which is a relatively higher standard than what is required to accept most other contract clauses. ${ }^{92}$ Weaver introduced this high

81. 397 U.S. 203, 211-17 (1970) (establishing guidelines for enforcing indemnification agreements for another's negligence, though ultimately holding that no express intention to do so was stated in the agreement at bar).

82. See, e.g., Ayer, 4 Mass. at 373; Hamaker, 2 Binn. at 509; Hoffman, 6 N.J.L. at 429-30; Stewart, 2 Cai. R. at 150-51; Steele, 33 Va. at 547.

83. Pfander \& Hunt, supra note 35, at 1889.

84. Id.

85. Id. at 1894-1905.

86. See, e.g., Eagle Ins. Co. v. Lafayette Ins. Co., 9 Ind. 422, 423-24 (1857); Lewis v. Richey, 5 Ind. 168 (1854); Gallion v. M'Caslin, 1 Blackf. 91, 93 (Ind. 1820); Clark v. Goodwin, 1 Blackf. 74, 75-76 (Ind. 1820).

87. See, e.g., Horn v. Bray, 51 Ind. 555, 560 (1875); Gwinn v. Hubbard, 3 Blackf. 14, 15-16 (Ind. 1832).

88. 276 N.E.2d 144, 148 (Ind. 1971).

89. See, e.g., Loper v. Standard Oil Co., 211 N.E.2d 797 (Ind. Ct. App. 1965); Franklin Fire Ins. Co. v. Noll, 58 N.E.2d 947 (Ind. Ct. App. 1945).

90. 276 N.E. $2 d$ at 148 .

91. Id.

92. See, e.g., id. at 146-48 (finding that an indemnification clause in fine print and in the middle of a paragraph with no heading was not "knowingly" or "willfully" entered into); Maxon 
standard because Indiana courts generally disfavor these provisions; ${ }^{93}$ moreover, this is true in almost all jurisdictions. ${ }^{94}$ Though disfavored, no public policy exists to prevent indemnity agreements for another's negligence, save in cases of fraud, unconscionability, unequal bargaining power, or certain public interests. ${ }^{95}$

In order for an agreement to be willingly and knowingly entered into, courts strictly interpret proposed agreements and require the language to expressly state in "clear and unequivocal" terms" that the indemnitor intends to cover the indemnitee for the latter's own negligence. " "To be 'clear and unequivocal' the clause must define the "cause [of damage] in terms of legal or physical responsibility." "97 Stated another way, "[t]he concern with the language of an indemnity clause in this area is that it not only define the area of application, that is, negligence, but also define the cause of damages in terms of physical or legal responsibility, that is, to whom the clause applies." 98 As summarized in Hagerman Construction Corporation v. Long Electric Company, the modern analysis for the validity of these types of indemnity agreements simplifies into a brief two-step test:

First, the indemnification clause must expressly state in clear and unequivocal terms that negligence is an area of application where the indemnitor has agreed to indemnify the indemnitee. The second step determines to whom the indemnification clause applies. Again, in clear and unequivocal terms, the clause must state that it applies to indemnification of the indemnitee by the indemnitor for the indemnitee's own negligence. ${ }^{99}$

\section{E. The Question Restated and Other Jurisdictions}

Though it is commonplace in most jurisdictions for the government to seek contractual indemnity from a private entity, ${ }^{100}$ very few cases, outside of In re

Corp. v. Tyler Pipe Indus., Inc., 497 N.E.2d 570, 577-78 (Ind. Ct. App. 1986) (finding an indemnification clause near the bottom of a long paragraph entitled "warning and covenants,"

where the first two thirds discussed installation and maintenance issues, was not "knowingly" or "willfully" entered into).

93. Moore Heating \& Plumbing, Inc. v. Huber, Hunt \& Nichols, 583 N.E.2d 142, 145-46 (Ind. Ct. App. 1991).

94. United States v. Seckinger, 397 U.S. 203, 211 (1970).

95. General Bargain Center v. American Alarm Co., Inc., 430 N.E.2d 407, 411-12 (Ind. Ct. App. 1982).

96. Ogilvie v. Steele, 452 N.E.2d 167, 170 (Ind. Ct. App. 1983) (citing Vernon Fire \& Cas. Ins. Co. v. Graham, 336 N.E.2d 829, 831 (Ind. Ct. App. 1975)).

97. Id.

98. Moore Heating \& Plumbing, Inc., 583 N.E.2d at 145.

99. 741 N.E.2d 390, 392 (Ind. Ct. App. 2000).

100. See, e.g., State v. Korean Air Lines Co., 776 P.2d 315, 316 (Alaska 1989); Greer v. City of Phila., 795 A.2d 376, 377 (Pa. 2002); Revel v. Am. Exp. Lines, Inc., 162 F. Supp. 279, 288 (E.D. 
Indiana State Fair Litigation, have considered the reverse and whether it would undercut that jurisdiction's respective Tort Claims Act. The question is novel in most jurisdictions, including Indiana., and several state jurisdictions have narrowly avoided a question similar to In re Indiana State Fair Litigation by resolving similar issues on different grounds. ${ }^{101}$ However, despite the states' apprehension to address the question, the federal government has addressed this problem to an extent ${ }^{102}$ and it allows claims of express indemnity against it, despite the Federal Tort Claims Act, provided it is in the bounds of the Tucker Act. ${ }^{103}$ The Tucker Act allows federal district courts to entertain claims for "[a]ny . . . civil action or claim against the United States, not exceeding $\$ 10,000$ in amount, founded ... upon any express or implied contract with the United States." ${ }^{104}$ This includes claims pursuant to the government's express agreement to indemnify a private party. ${ }^{105}$

For example, in Lopez v. Johns Manville, a private contractor sought to compel the United States to indemnify them pursuant to implied, common law indemnity. ${ }^{106}$ The district court dismissed the charges, noting that the AntiDeficiency Act (31 U.S.C. $§ 1341$ ), which prohibits an agency from committing

Va. 1958).

101. See, e.g., Union P. R. Co. v. Kaiser Agric. Chem. Co., 425 N.W.2d 872, 879 (Neb. 1988) (finding an employer who might gain immunity under the Nebraska Worker's Compensation Act might nonetheless be exposed to liability pursuant to an indemnity agreement); Whittle v. Pagani Bros. Constr. Co., 422 N.E.2d 779 (Mass. 1981) (noting a defendant claiming express contractual indemnity may implead the plaintiff's employer despite provisions releasing the employer from tort claims of the employee); Teachy v. Coble Dairies, Inc., 293 S.E.2d 182, 186-87 (N.C. 1982) (finding that, due to partial abrogation of the North Carolina Tort Claims Act, the State might be compelled to indemnify a third party under a common law theory); Wells v. State, 435 S.W.3d 734, $749 \mathrm{n} .10$ (Tenn. Ct. App. 2013) (declining to address the question of whether an express indemnity agreement against the State would be an improper abrogation of the State's immunity); see also Renna Rhodes, Principals of Governmental Immunity in Texas: The Texas Government Waives Sovereign Immunity when it Contracts-Or Does it?, 27 ST. MARY's L. J. 679, 682-84 (1996) (discussing that although Texas typically allowed contract claims against the state, recent case law has created some exceptions).

102. The difficulty of a parallel comparison to the federal practice is that the relevant federal statute, the Tucker Act, levies a $\$ 10,000$ statutory cap on contracts of this nature; whereas other statutory caps, including Indiana's, deal with caps on tort claims, not contract claims. As such, though persuasive, these sources may only be taken with a grain of salt. See Tucker Act, 28 U.S.C. $\S 1346(\mathrm{a})(2)(2012)$.

103. Brocklesby v. United States, 767 F.2d 1288, 1293 (9th Cir. 1985); see also Hillier v. S. Towing Co., 714 F.2d 714, 726 (7th Cir. 1983) (noting that, despite the Federal Tort Claims Act, under the Tucker Act the government might be exposed to liability via express contract including indemnification).

104. 28 U.S.C. $\S 1346(\mathrm{a})(2)$.

105. See, e.g., Brocklesby, 767 F.2d at 1293; Friends for All Children, Inc. v. Lockheed Aircraft Corp., 567 F. Supp. 790, 796 n.6 (D.D.C. 1983).

106. 649 F. Supp. 149, 157 (W.D. Wash. 1986). 
to a contract before appropriations are made to fund such an agreement, trumped any claims under the Tucker Act. ${ }^{107}$ However, assuming that the agency had the proper authority and that such appropriations were made, the court still concluded that the United States could not be compelled to indemnify the private entity because the Tucker Act only covered claims brought pursuant to an express or implied-in-fact contract; not a contract implied in law. ${ }^{108}$ In so holding, the court reaffirmed the conclusion that if an agency of the United States had the valid grant of power to enter into an express contract to indemnify a private party, that party could seek indemnification from the government --at least to the breadth permitted by the $\$ 10,000$ cap. ${ }^{109}$

\section{Key Distinctions Between the Protections Negotiated for in AN IndEMNIFICATION AgREEMENT AND PROTECTIONS AFFORDED BY THE ITCA}

\section{A. Differing Thresholds of Intent: Negotiated Versus Inherent}

Perhaps the biggest distinction between the liability conferred by an indemnity agreement and the liability conferred under common tort is the threshold intent necessary to confer those liabilities. ${ }^{110}$ In order for the State to be liable under an express indemnity agreement, a proponent must demonstrate, while under considerable scrutiny, ${ }^{111}$ that the contract was entered into willingly and knowingly and that the terms of the agreement are "clear and unequivocal."112 As such, the liability conferred in this manner may be characterized as negotiated or deliberate because it can only be conferred through some intentional process-typically a negotiation table. ${ }^{113}$

However, to be liable under the ITCA or common tort law, no threshold intent is required; the State could be liable potentially for the simple negligence of one of its workers or agents. ${ }^{114}$ One may bring the cause so long as it is not exempted by the statute. ${ }^{15}$ As such, the liability conferred to the State in this manner is the liability inherent to any actor potentially capable of committing a tort. Accordingly, the liability can be understood as inherent.

107. Id. at 159 .

108. Id. at $159-61$.

109. Id.

110. See generally Lawrence Rosenthal, A Theory of Governmental Damages Liability: Torts, Constitutional Torts, and Takings, 9 U. PA. J. ConsT. L. 797, 822-23 (2007); Bruce H. Schoumacher, Risk Management and Indemnity § 4-13, in CONSTRUCTION LAw 13.17 (Steven G.M. Stein ed., 2010).

111. Weaver v. Am. Oil Co., 276 N.E.2d 144, 148 (Ind. 1971).

112. Ogilvie v. Steele, 452 N.E.2d 167, 170 (Ind. Ct. App. 1983).

113. See Schoumacher, supra note 110.

114. See, e.g., Januchowski v. N. Ind. Commuter Transp. Dist., 905 N.E.2d 1041 (Ind. Ct. App. 2009); Cantrell v. Morris, 849 N.E.2d 488, 498 (Ind. 2006); Lachenman v. Stice, 838 N.E.2d 451, 461 (Ind. Ct. App. 2005).

115. See Ind. CodE $\S 34-13-3-3$ (2016). 
Although the State might be exposed to liability unknowingly under common tort, the State must willingly and knowingly accept the liability under an indemnity agreement; furthermore, liability via contractual indemnity is only possible by the State's own choice and never by a set of circumstances unwillingly thrust against the State, as is the case with negligence. ${ }^{116}$ Thus, the threshold intent to confer liability for indemnity is much higher than the standard for common tort and can only be reached by the State's conscious volition. ${ }^{117}$

\section{B. Differing Liabilities}

Indemnification is derivative in nature, meaning that no financial liability can exist until some actual liability has accrued between two other parties. ${ }^{118}$ For example, if A has agreed to indemnify B for B's negligence, A cannot be liable to $\mathrm{C}$ until B's negligence injures $\mathrm{C}$. Thus, in the civil context, liability can be split into actual and what might be dubbed "financial"" liability. ${ }^{119}$ Financial liability or the duty to pay another cannot exist until one party has been found liable actually to another. ${ }^{120}$ So in the earlier example, A could not be liable financially to $\mathrm{C}$ until $\mathrm{B}$ was found liable actually for C's resulting damages.

Traditionally, many commentators have lumped financial liability and actual liability together into "liability" when referring to what is shifted by indemnification. ${ }^{121}$ For private, two-party claims this is perhaps a minute detail, as the two liabilities end up being one in the same and largely indistinguishable from each other. However, because indemnity agreements separate the liabilities between two or more parties, it can become confusing when trying to discuss both liabilities simultaneously. ${ }^{122}$

Tort liability encompasses both actual and financial liability and is thus distinguished from loss spreading tools which only encompass financial liability. ${ }^{123}$ As stated by Professor Lawrence Rosenthal, "[t]he two major schools of thought about tort law share the objective of shifting losses to culpable parties; hence both distinguish tort law from mere loss-spreading through insurance by

116. See generally Weaver, 276 N.E.2d at 148.

117. See generally id.; Ogilvie, 452 N.E.2d at 170.

118. See Schoumacher, supra note 110.

119. Id.

120. Id.

121. See, e.g., Laura O'Rourke, A Manufacturer's Duty to Indemnify a RetailerIndemnification or Abnegation? An Analysis of the Scope and Effect of Section 82.002 of the Texas Products Liability Act, 33 Tex. Tech L. ReV. 241, 255 (2001); Gilson S. Riecklen, The Duty to Defend Under Non-Insurance Indemnity Agreements: Crawford v. Weather Shield Manufacturing, Inc. and Its Troubling Consequences for Design Professionals, 50 SANTA ClARA L. ReV. 825, 828 (2010); Roger W. Stone \& Jeffrey A. Stone, Indemnity in Iowa Construction Law, 54 DraKe L. REV. 125, 126-27 (2005).

122. See generally Schoumacher, supra note 110.

123. See Rosenthal, supra note 110. 
means of a conception of culpability." ${ }^{124}$ Simplified, pure tort liability is constituted by both actual liability and financial liability because society has deemed that a culpable party should reimburse the party they injured. ${ }^{125}$ Indemnification agreements, however, target a wholly distinct liability to manage, namely solely financial liability. ${ }^{126}$ In fact, this may have been what Justice Holmes was describing when he characterized tort claims as "forced" indemnity. ${ }^{127}$ Ultimately then, it is impossible for an indemnity agreement to undercut the ITCA because the ITCA is only aimed at protecting the State from tort liability, not from the distinct financial liability.

\section{Differing Policy Motivations}

Though once an academic exercise stemming from the bowels of monarchy and theocracy, sovereign immunity in Indiana has been transformed and predicated repeatedly on the justification of protecting the public treasury. ${ }^{128}$ Both before and after the ITCA was passed, this was, and still is, the key purpose ${ }^{129}$ along with the additional purposes of promoting the discretion of government employees, and incentivizing workplace safety. ${ }^{130}$ However, these same motivations were present when common law immunity was all but abolished in Campbell. ${ }^{131}$ In Campbell, the Indiana Supreme Court took a strong stance against the idea of economic doom due to increased government liability:

The argument has been presented that elimination of the doctrine of sovereign immunity will impose a disastrous financial burden upon the state. Assuming there is any relevancy to this contention, we point out that the abrogation of sovereign immunity on the state level is consistent with conditions already existing in cities and counties in this state. If city and county governments can withstand the consequences of such

124. Id. at 822-23 (emphasis added).

125. See generally id.

126. For discussion concerning indemnity as solely a financial risk shifting device, see Rheem Mfg. Co. v. Phelps Heating \& Air Conditioning, 746 N.E.2d 941, 950 n.8 (Ind. 2001); Mindy Olson, The Statute of Limitations for Indemnification When No Charges are Filed: How Soon is a Director Required to Make a Claim?, 31 IowA J. CoRP. L. 1035, 1038-39 (2006); Charles Daugherty, Note, Who Needs Contract Law? - A Critical Look at Contractual Indemnification (or Lack Thereof) in FHAA and ADA "Design and Construct" Cases, 44 IND. L. REV. 545, 564-65 (2011).

127. See John C. P. Goldberg, Ten Half-Truths About Tort Law, 42 VAL. U.L. REV. 1221, 1255-56 (2008).

128. Campbell v. State, 284 N.E.2d 733, 736 (Ind. 1972), superseded by statute, Indiana Tort Claims Act, IND. CoDE $\S \S 34-13-3-0.1$ to -25 (2016), as recognized in Cantrell v. Morris, 849 N.E.2d 488, 495 (Ind. 2006).

129. Id.; In re Train Collision at Gary, 654 N.E.2d 1137, 1146 (Ind. Ct. App. 1995).

130. Bd. of Comm'rs v. King, 481 N.E.2d 1327, 1330 (Ind. Ct. App. 1985); Clark C. Johnson, Note, Collapsing the Legal Impediments to Indemnification, 69 IND. L.J. 867, 871-72 (1994).

131. 284 N.E.2d. at 737-38. 
liability, where traffic hazards seemingly are greater, the state should be able to also bear such burden. ${ }^{132}$

Taking the logic of Campbell to the next natural step, if the Supreme Court found that removing (practically) all sovereign immunity would not lead to an influx of judgments against the State, it is difficult to see how an agreement, entered into voluntarily by the State, would lead to an influx of unwanted judgments when the State could deliberately control any risk by simply not entering into the agreement.

Proponents of the ITCA also argue, in addition to impending financial doom, that removing this immunity would incentivize negligence for indemnified parties; however, there is no reason to believe this. ${ }^{133}$ There are numerous other incentives for an indemnified party (typically general contractors) to continue to emphasize safety (productivity, time, morale, etc.). ${ }^{134}$ Further, even the most artfully crafted indemnity agreement may not cover all or part of the potential liability brought against the party negotiating for indemnity. ${ }^{135}$ Perhaps channeling the old adage "better safe than sorry," these motivations continue to incentivize safety despite an indemnity agreement.

As opposed to the ITCA's motivations, indemnity is a risk-allocation tool. ${ }^{136}$ The purpose is economic in nature-it gives the parties direct control over their risk and lets them either insure themselves for additional consideration or garner a cheaper contract with the risk of potential financial liability. ${ }^{137}$ Thus, the policies behind the ITCA cannot be undermined where the potential unwanted suits can be completely controlled by the State through a risk allocation tool; the State would not take any more risk than what it agreed to take. Additionally, there is no reason to think that employee discretion or workplace safety would be undermined by allowing the government to enter into these agreements.

\section{Differing Natures: Contract Versus Tort}

The traditional notion was that something could not be based both in contract and tort: it had to be one or the other. ${ }^{138}$ Despite appearing seemingly unimportant, this issue can be crucial in determining the subject matter jurisdiction of a court, especially at the federal level, which typically does not

132. Id. at 736 .

133. Johnson, supra note 130.

134. Id.

135. Id.

136. See Rheem Mfg. Co. v. Phelps Heating \& Air Conditioning, 746 N.E.2d 941, 950 n.8 (Ind. 2001); Olson, supra note 126; Daugherty, supra note 126.

137. Schoumacher, supra note 110.

138. Anderson Foundry \& Mach. Works v. Myers, 44 N.E. 193, 194-95 (Ind. Ct. App. 1896) (noting, "[i]t is difficult to see how the same transaction can be made the basis for both a tort and a contract" and that "a party has the right to elect to treat a transaction as a tort or as a contract . . ..”.). 
delve into state law issues like contracts. ${ }^{139}$ Sometimes too, the distinction remains important for the sake of particular statutes, like statutes of repose. ${ }^{140}$

But this traditional view came almost a century before the rise in popularity of the contemporary indemnity agreement. ${ }^{141}$ Courts seem willing now to treat indemnification as a gray area which has the potential to sound in either contract or torts. ${ }^{142}$ For example, modern courts and commentators appear to define something as a contract or a tort based on its genesis, not on a hard and fast definition. ${ }^{143}$ For example, Comment (b) of Section 76 of the Restatement First of Restitution states that a claim concerning an agreement to indemnify is governed by the contract because that is what created the duty. ${ }^{144}$ That is juxtaposed by common law indemnity which is governed solely by tort law because it was the relationship of the tortfeasor to the other party that created the duty on the tortfeasor, not an express contractual term. ${ }^{145}$ Thus a negotiated indemnity agreement is not even the type of claim that the ITCA was designed to prevent, as an express indemnity agreement is solely a question of contract law, not tort liability. ${ }^{146}$

Consider for example, Unincorporated Operating Division of Indiana Newspapers, Inc. v. Trustees of Indiana University, which involved the alleged waiver of statutory immunity by a State agency under the Indiana Access to Public Records Act (IAPRA). ${ }^{147}$ The IAPRA was enacted to prevent public

139. See, e.g., CTA Inc. v. United States, 44 Fed. Cl. 684, 697-98 (1999) (noting the court only had subject-matter jurisdiction over contract claims permitted by the Tucker Act, not tort claims).

140. See, e.g., Town of Weymouth v. James J. Welch \& Co., 6 Mass. L. Rep. 197, 201-06 (Super. Ct. 1996) (determining if a claim sounded in tort for the purpose of a statute of repose).

141. Note that Anderson came almost seventy years prior to the United States Supreme Court's Seckinger decision, which stimulated the popularity of hold harmless agreements.

142. Restatement (First) Of Restitution $\S 76$ cmt. b (1937).

143. See Commercial Union Ins. Co. v. Pittsburgh Corning Corp., 789 F.2d 214, 218 n.5 (3d Cir. 1986) (emphasizing that any duty to defend and duty to indemnify, are not linked as "principle[s] of law" but depend entirely on the contract that created them); W.M. Schlosser Co. v. Md. Drywall Co., 673 A.2d 647, 653 n.13 (D.C. 1996) (stating that a tort-based bar would not apply to an express indemnity agreement because it "does not sound in tort"); Kennedy v. Sawyer, 618 P.2d 788, 799 (Kan. 1980) (noting “[express] indemnity is a creature of contract”); Roderick v. Bugge, 584 F. Supp. 626, 630 (D. Mass. 1984) (stating that a common law tort theory of indemnification exists, in some circumstances, based on the relationship of the tortfeasors and the cause of the injury); accord Indianapolis Power \& Light Co. v. Brad Snodgrass, Inc., 578 N.E.2d 669, 671-72 (Ind. 1991); Schneider Nat'l v. Holland Hitch Co., 843 P.2d 561, 573 (Wyo. 1992).

144. Restatement (First) OF Restitution $\S 76 \mathrm{cmt}$. b (1937).

145. See generally Fulton v. Chi., R. I. \& P. R. Co., 481 F.2d 326, 332 (8th Cir. 1973); Indianapolis Power \& Light Co., 578 N.E.2d at 671.

146. See generally Restatement (First) of Restitution $\S 76$ cmt. b (1937); Fulton, 481 F.2d at 332; Indianapolis Power \& Light Co., 578 N.E.2d at 671.

147. 787 N.E.2d 893 (Ind. Ct. App. 2003). 
entities from having to disclose certain documents and statements. ${ }^{148}$ Here, a newspaper sought information concerning the termination of legendary basketball coach Bob Knight, and asserted that Indiana University had waived its statutory immunity from disclosing these documents. ${ }^{149}$ Even though the court ultimately found that the University had not waived its immunity the court noted:

We can envision a situation in which a state agency might relinquish the protections afforded by [the statute] .... Nor do we believe that such a conclusion would frustrate the underlying purpose of the [statutory] exceptions, for if the agency has already [waived its immunity], the purpose of the [statutory] exceptions will have already been compromised. ${ }^{150}$

Put in layman's terms, if the agency had already voluntarily waived its protections, then it would be at that point that the purpose of the statute might have been frustrated, not the court's choice to enforce it. ${ }^{151}$

Considering all four critical distinctions, it is apparent that allowing the State to expressly indemnify a private party would not violate or even abrogate the purpose, function, or scope of the ITCA. Tort liability under the ITCA would still remain at its current low thresholds of intent because the agreements would require a higher threshold to reach and therefore it would be no easier to levy unwanted claims against the State than it has been. ${ }^{152}$ Next, the tort liability from which the ITCA was envisioned to protect the State would still be guarded against because the liability any contractual indemnity would levy would be of a distinct, financial variety. ${ }^{153}$ Moreover, the chief theoretical motivation behind the ITCA of preventing excess tort suits would still not be disturbed because it could be directly controlled by the State via negotiating what potential risk they would be willing to assume. ${ }^{154}$ Further, the very scope of the ITCA is not disturbed because claims brought under indemnity agreements are contract claims which are not governed by the ITCA; thus there would be no corresponding increase or decrease in claims governed by the ITCA because the State allowed itself to contractually indemnify a party. ${ }^{155}$ Lastly, harkening to the rationale in Operating Division of Newspapers, even if the ITCA would be undermined by express indemnity, it would be the State's choice to sign the agreement, not the Court's decision to enforce that agreement that would undermine the purpose and the language of the ITCA. ${ }^{156}$ The blood would be wholly on the State's hands.

148. Id.

149. Id. at $918-19$.

150. Id. at 919 .

151. See id.

152. See Part II.A.

153. See Part II.B.

154. See Part II.C.

155. See Part II.D.

156. See Unincorporated Operating Div. of Ind. Newspapers, Inc. v. Trs. of Ind. Univ., 787 N.E.2d 893, 918-19 (Ind. Ct. App. 2003). 


\section{UNJUSTIFIED RESTRAINT}

\section{A. Judicial Acquiescence}

The State power to contract stems from its sovereignty and from its powers under the Tenth Amendment to the U.S. Constitution, which provides that those powers not expressly delegated to the federal government remain with the States and the citizens. ${ }^{157}$ By retaining these powers, the State Legislature is entitled to permit means for the State to enter into contracts for the peace, safety, health, happiness, and general well-being of its citizens. ${ }^{158}$ Once the legislature grants powers to an agency, it is not set in stone that powers not expressly given or denied are not available to the agency. ${ }^{159}$ If an agency were given broad contracting powers, express indemnity might fall under this inherently, as a natural corollary.

Though initially citizens were barred from bringing suit against the State to enforce a contract, the 1851 Indiana Constitution opened the door for the Indiana Legislature to pass acts permitting contract claims to be levied against the State. ${ }^{160}$ In the monumental decision Carr v. State (1891), the Indiana Supreme Court ratified this idea by permitting creditors of the State's debt, prior to the new Constitution, to seek payment. ${ }^{161}$ In so holding, the Indiana Supreme Court recognized the equality in treatment and standing before the law, as it relates to a contract between the State and a private party:

As there is a perfect contract, the State is bound to perform it according to its legal tenor and effect, and to redeem the pledge it has declared to be irrevocable. In entering into the contract it laid aside its attributes as a sovereign and bound itself substantially as one of its citizens does when he enters into a contract. Its contracts are interpreted as the contracts of individuals are, and the law which measures individual rights and responsibilities measures ... those of a State whenever it enters into an

157. U.S. Const. amend. X; Cent. Union Tel. Co. v. Indianapolis Tel. Co., 126 N.E. 628, 632 (Ind. 1920).

158. Cent. Union Tel. Co., 126 N.E. at 632.

159. See, e.g., Ind. Farm Gas Prod. Co. v. S. Ind. Gas \& Elec. Co., 662 N.E.2d 977, 983 (Ind. Ct. App. 1996) ("It is well-settled that an administrative agency has the inherent authority in its broad grant of power from the legislature to regulate that which is necessary to effectuate the regulatory scheme outlined in the statute.") (citing N. Ind. Pub. Serv. Co. v. Citizens Action Coal. of Ind., 548 N.E.2d 153, 161 (Ind. 1989)); Dale Bland Trucking, Inc. v. Calcar Quarries, Inc., 417 N.E.2d 1157, 1159 (Ind. Ct. App. 1981) ("Even where legislative direction is absent or unclear, some courts have held that the agency has some inherent power to reopen orders."); Ind. Tel. Corp. v. Ind. Pub. Serv. Com., 171 N.E.2d 111, 131 (Ind. Ct. App. 1960) (finding that a State agency held the "inherent or implied powers to grant a rehearing, and to hold a new hearing, on appellant's petition for increase in rates").

160. State v. Rendleman, 603 N.E.2d 1333, 1335 (Ind. 1992).

161. 26 N.E. 778, 778-79 (Ind. 1891). 
ordinary business contract. ${ }^{162}$

Reemphasized in State v. Feigel, a contract between the State and a private party is treated as if it were a contract between two private parties: "The truth is, states and cities, when they borrow money, are not acting as sovereignties. They come down to the level of ordinary individuals. Their contracts have the same meaning as that of similar contracts between private persons." 163

To illustrate this point, consider State v. Snyder. In Snyder, the State hired a contractor to build a new highway. ${ }^{164}$ Per the agreement, the State would secure the right of way for all the land which the highway was to occupy. ${ }^{165}$ However, after work was already started, the State had failed to procure the necessary right of way; by the time all the right of ways were secured, the project had been delayed by two years and had accumulated significant damages associated with the delay. ${ }^{166}$ The State argued it could not be held accountable for that portion of the contract because that term concerned a government function and the principles of sovereignty barred the State from failing to conduct a government function. ${ }^{167}$ The court of appeals disagreed, holding that if the State agreed to a term, it would be held responsible for its performance, just like a private citizen, even if the term was a government function. ${ }^{168}$

The equal treatment is even more meaningful when one considers that the Indiana Supreme Court has expressly rejected equality before the law in other areas, like torts. ${ }^{169}$ As such, the Indiana Supreme Court has implicitly recognized the important distinction between risks that the State has voluntarily taken on and the involuntary risks which the State incurs through the performance of its essential government function. ${ }^{170}$ Further, as stated in Carr and Feigel, the State abandons its properties as a sovereign upon entry into a contract. Defenses normally available to a sovereign, like immunity, cannot be allowed in these situations lest the State be allowed an arsenal not available to private defendants. Thus, to permit an immunity defense would be an unjustified restraint on the judicially prescribed equality in contracts, established for over a century in Indiana.

\section{B. Legislative Acquiescence}

The idea of express indemnity has grown in prolificacy and is largely a new area of the law in most states, including Indiana. ${ }^{171}$ In response to this growing

162. Id. at 779 (emphasis added).

163. 178 N.E. 435, 437 (Ind. 1931) (citing Murray v. Charleston, 96 U.S. 432, 445 (1877)).

164. 183 N.E. 680, 680-81 (Ind. Ct. App. 1932).

165. Id.

166. Id.

167. $I d$. at 681 .

168. Id. at 681 .

169. Ind. State Highway Comm'n v. Curtis, 704 N.E.2d 1015, 1020 (Ind. 1998).

170. Id.

171. See, e.g., Weaver v. Am. Oil Co., 276 N.E.2d 144, 148 (Ind. 1971) (holding for the first 
popularity, the Indiana Code expanded many of its sections to consider them. ${ }^{172}$

Many of these statutes include express references when the State has forbid itself from indemnifying another party or when the General Assembly found such an agreement to be void as against public policy. ${ }^{173}$ But in many other instances, the State has granted an agency broad contracting powers and made no mention of express indemnity. ${ }^{174}$ Thus, the General Assembly is familiar with indemnification and agreements for indemnity and when they wished it, they have taken steps to limit it. So, when the Legislature has given broad contracting powers to an agency, but not expressly forbidden it from entering into an indemnity agreement, the evidence suggests that the State is aware of the implications of its decision. ${ }^{175}$ As such, it would be an unjustified restraint on the State's contracting powers to prevent it from entering into such an agreement when broad contracting powers are given.

\section{Equitable Concerns-INequity of Protections}

\section{A. Equitable Concerns and Estoppel}

This Note is based on the assumption that the relevant agency would have the necessary contracting powers for an indemnity agreement. Disregarding that assumption though for this section, equity demands, in situations akin to In re Indiana State Fair Litigation, that the government be enjoined from reneging on its deal.

Not all contracts entered into by a state agency automatically bind the State. ${ }^{176}$ For example, a contract entered into by a municipal corporation or an agent "ultra vires," or without the legal authority to do so, would be void as

time that parties might agree to express indemnification); Corrao Constr. Co. v. Curtis, 584 P.2d 1303, 1304 (Nev. 1978) (finding for the first time that the NITA did not allow express indemnification); Kirk H. Nakamura, Krusing for a Bruising: Is Total Express Immunity Dead?, 38 ORAnge CNTY LAW. 34, 34 (1996) (noting California's first case addressing express indemnification was in 1975).

172. In comparing 1991's version of the Indiana Code with 2016's version, a search of statutory code, referencing "indemnity" or its derivatives, yields an increase of as many as one hundred additional hits, using a cross reference of WestlawNext and Lexis Advance. Additionally, in performing the same comparison search of Indiana statutory code, referencing "indemnity" or its derivatives within five words or less of "agree," "contract," or "express" and their derivatives, yields an increase of no fewer than twenty-five additional hits, using a cross reference of WestlawNext and Lexis Advance.

173. See, e.g., IND. CODE $\S \S 26-2-5-1,13-24-1-5,8-2.1-26-5$ (b), 13-23-13-10 (2016).

174. See, e.g., IND. CODE § 15-13-3-4 (2016) (stating " [t] he commission may ... [e]nter into contracts related to the commission's powers and duties under this article[,]" but making no mention of any prohibition on the kind of contract into which the commission might enter).

175. See, e.g., IND. CoDE $\S \S 26-2-5-1,13-24-1-5,8-2.1-26-5$ (b), 13-23-13-10 (2016).

176. Muncie Nat. Gas Co. v. Muncie, 66 N.E. 436, 438-39 (Ind. 1903). 
against public policy, lest injustice would be caused by it. ${ }^{177}$ In Frankfort v. Logan, the city of Frankfort dismissed Officer Logan and Logan brought suit for reinstatement and back wages via breach of contract. ${ }^{178}$ The relevant statute at issue prevented the city from hiring new, "regular" police officers if the officer was older than the age of thirty-five. Logan was forty-two when he was originally hired ${ }^{179}$ Reversing the trial court, the Indiana Court of Appeals found Logan had no claim against the city because the agency that hired him had entered into a contract ultra vires, and the contract was therefore void and unenforceable. ${ }^{180}$

As a general rule, besides ultra vires contracts, when a party contracts against the mandate of a statute, the contract is void. ${ }^{181}$ However, this is not always the case where inequity would result or where the purpose of the statute would be defeated. ${ }^{182}$ Indiana courts also typically do not allow the doctrine of estoppel to be used against the government for policy reasons, ${ }^{183}$ but courts will allow the doctrine where "'the public interest would be threatened by the government's conduct." "184 Indiana Courts have not defined specific public interest categories; ${ }^{185}$ rather, they ask that proponents of an estoppel claim " "[articulate a] public policy reason which the court determines outweighs the public policy that supports denying estoppel.",186

In general, the Founding Fathers often described government as a trust ${ }^{187}$ for

177. Id.; Seemless Pressed Steel \& Mfg. Co. v. Monroe, 106 N.E. 538 (Ind. Ct. App. 1914) (noting, "It would be carrying that doctrine to an unwarranted extent, however, to hold that a corporation might obtain the money of another, and, with the fruits of the contract in its treasury, interpose the defense of ultra vires.").

178. 341 N.E.2d 510, 511-12 (Ind. Ct. App. 1976).

179. Id. at 511-13.

180. Id. at 514-15.

181. See, e.g., Hamer v. Huntington, 21 N.E.2d 407, 411-12 (Ind. 1939) (finding payment for a fire truck was properly refused where payment was not established before the contract was executed); Bd. of Comm'rs v. Gillies, 38 N.E. 40, 42 (Ind. 1894) (holding a board that failed to hear additional bids on a project, in violation of statutory requirements, had entered into a void contract and was prohibited from executing it); but cf. State v. Am. Motorists Ins. Co., 463 N.E.2d 1142, 1148 (Ind. Ct. App. 1984) (holding that, despite improper compliance with the statute, the State was permitted to entertain an action on a void contract where the usual result would run counter to the purpose of the statute's inception).

182. See Am. Motorists Ins. Co., 463 N.E.2d at 1147-48 n.5; Peter \& Burghard Stone Co. v. Carper, 172 N.E. 319, 328 (Ind. Ct. App. 1930); see also City of Mishaw v. Kvale, 810 N.E.2d 1129 (Ind. Ct. App. 2004).

183. Hi-Way Dispatch v. Ind. Dep't of State Revenue, 756 N.E.2d 587, 598 (Ind. T.C. 2001) (citing Gressley v. Califano, 609 F.2d 1265 (7th Cir. 1979)).

184. Id. at 598-99 (quoting Metro. Dev. Comm'n v. Schroeder, 727 N.E.2d 742, 752 (Ind. Ct. App. 2000)).

185. Samplawski v. Portage, 512 N.E.2d 456, 459 (Ind. Ct. App. 1987).

186. Hi-Way Dispatch, 756 N.E.2d at 599 (quoting Samplawski, 512 N.E.2d at 459.).

187. See The Federalist No. 46 (James Madison) (describing the Government as a trust for the people's benefit); THE ANTI-Federalist PAPERS 40 (James Wilson) (emphasizing that the 
the sole purpose of achieving happiness. ${ }^{188}$ Though speaking about potential sources of hostility between powerful, coequal states (as was the case under the Articles of Confederation), Alexander Hamilton identified laws which violated private contract rights as a key source of anger, hostility, and disunity between the states and their citizens. ${ }^{189}$ In harmony with Hamilton, James Madison warned his readers generally about creating laws that would directly violate beneficial social constructs, like contracts: "Bills of attainder, ex post facto laws, and laws impairing the obligation of contracts are contrary to the first principles of the social compact, and to every principle of sound legislation[,] . . all of them are prohibited by the spirit and scope of [the Constitution]." 190

By allowing the ITCA to extend to matters of private contract rights, it could potentially create a source of hostility and undermine the public confidence and trust in the government. ${ }^{191}$ As recounted by Justice Field:

The interference with contracts by the legislation of the several States previous to the adoption of the Constitution was the cause of great oppression and injustice. "Not only ... was paper money issued and declared to be a tender in payment of debts, but laws of another character ... were from time to time enacted, which prostrated all private credit and all private morals. By some of these laws the due payment of debts was suspended; debts were, in violation of the very terms of the contract, authorized to be paid by installments at different periods; property of any sort, however worthless, either real or personal, might be tendered by the debtor in payment of his debts, and the creditor was compelled to take the property of the debtor, which he might seize on execution, at an appraisement wholly disproportionate to its known value. Such grievances and oppressions [took up the Revolutionary period]. [These laws] entailed the most enormous evils on the country and introduced a system of fraud, chicanery, and profligacy, which destroyed all private confidence and all industry and enterprise." 192

To allow the government to hide behind immunity after negotiating for a lower contract rate (because of an indemnity provision) would constitute an abhorrent "gotcha" moment. ${ }^{193}$ Even more so, the sanctity of contracts, as realized

Government requires the public confidence to sustain itself).

188. See, e.g., The Federalist No. 40 (James Madison); The Federalist No. 62 (James Madison); The FEDERALIST No. 78 (Alexander Hamilton).

189. The Federalist No. 7, at 59-60 (Alexander Hamilton) (Clinton Rossiter ed., 1961).

190. The Federalist No. 44, at 278-79 (James Madison) (Clinton Rossiter ed., 1961).

191. See The Federalist No. 7, supra note 189.

192. Legal Tender Cases, 79 U.S. (12 Wall.) 457, 666-67 (1871) (Field, J., dissenting) (quoting Joseph Story, Commentaries on the CONSTitution, § 1371 (1833)).

193. Such prejudice was the same kind of threat "natural and immutable justice," which inspired many important legal theories like unjust enrichment. Bayh v. Sonnenburg, 573 N.E.2d 398, 408 (Ind. 1991) (citing Clark v. Peoples Sav. \& Loan Ass'n, 46 N.E.2d 681, 682 (Ind. 1943) ("A quasi-contract ... 'is a legal fiction invented ... where the circumstances are such that under 
by Justice Field, is an essential underpinning of the American economic system. ${ }^{194}$ Though certainly not absolute or unrestrained, ${ }^{195}$ parties generally have a right to what they negotiated.

Despite being far removed from the days of Lochner v. New York, where the U.S. Supreme Court claimed the broad right of freedom to contract, ${ }^{196}$ it is a bold leap to suggest the State might not honor its contracts after negotiating for and receiving the benefit of the bargain. It seems appropriate then that where a government action (in this case reneging on a contract) would create a precedent running counter to a fundamental underpinning of the economic system, this would be a sufficient instance where a government action might threaten the public interest and thus reason to qualify these sorts of instances for estoppel.

\section{B. Unbalanced Extrajudicial Protections}

Besides the equitable questions, the State has a panoply of means to prevent itself from procuring financial liability under an express indemnification, outside of court. The agreement can only be entered into knowingly and willfully; thus the State could not assume any liability that it was not meaning to assume ${ }^{197}$ If it is a matter of controlling an overzealous agency, the legislature has routinely, expressly defined when certain government entities would or would not have the authority to enter into such agreements. ${ }^{198}$ Considering the large amount of precedent statutes and the low-salience of the topic, the General Assembly could easily pass a law limiting these specific contract powers in a state agency.

In stark contrast, outside of court, a private party would have a much more difficult time assuring redress for the State's refusal to honor an indemnity agreement. ${ }^{199}$ As was a concern even in the early republic, the Founders believed that it was best to let the judiciary adjudicate issues involving the government's financial liability because of the legislature's jealous hold on the power of the purse. ${ }^{200}$ This concern still holds water today as it appears to be the dictionary

the law of natural and immutable justice there should be a recovery as though there had been a promise."”)).

194. See Steven W. Feldman, Rescission, Restitution, and the Principle of Fair Redress: A Response to Professors Brooks and Stremitzer, 47 VAL. U. L. REV. 399, 406-07 n.37 (2013).

195. See generally K. M. Sharma, From "Sanctity" to "Fairness": An Uneasy Transition in the Law of Contracts?, 18 N.Y.L. SCH. J. INT'L \& COMP.L. 95, 111-15 (1999).

196. 198 U.S. 45 (1905), overruled by W. Coast Hotel Co. v. Parrish, 300 U.S. 379 (1937).

197. Moore Heating \& Plumbing, Inc. v. Huber, Hunt \& Nichols, 583 N.E.2d 142, 145-46 (Ind. Ct. App. 1991).

198. See, e.g., IND. CoDE $\S \S 26-2-5-1,13-24-1-5,8-2.1-26-5$ (b), 13-23-13-10 (2016). See also Polet v. Mid-Am. Sound (In re Ind. State Fair Litig.), 28 N.E.3d 333, 343 (Ind. Ct. App. 2015). Note that this case was overruled on its determination of the validity of the contract at issue, not on this point of law.

199. See generally David R. Mayhew, Congress: The Electoral Connection 115-18 (Yale Univ. Press, 2d ed. 2004).

200. See Pfander, supra note 35 , at 1871-74. 
definition of "conflict of interest" to leave a private indemnitee's fate up to the indebted party. ${ }^{201}$ Besides the legislature's conflict of interest, an appeal for new legislation would be unrealistic because of the difficulty for small, private, political outsiders to levy influence or mobilize the legislature to act in a favorable manner. ${ }^{202}$ This also ignores the large cost in time and resources such an effort would require, not to mention the numerous difficulties in passing new legislation, ${ }^{203}$ absent salience. Thus, it would be inequitable to ask the private party to seek extrajudicial relief when the State has more amenable routes to the same relief.

\section{IMPLICATIONS}

\section{A. More Careful Governance}

Allowing the State to execute indemnity agreements for another's negligence would likely foster more careful governance by the State because it will reassert the need for the State to read the contracts they are signing-something that the citizens of Indiana have long been lectured about. ${ }^{204}$ As the alternative stands, in cases like In re Indiana State Fair Litigation, the government could potentially be excused from its own negligence via not reading the terms to which it is agreeing. ${ }^{205}$ If nothing else, it will reassert the principles of Carr and Feigel that the State and private citizens are treated equally under contract law. Difficulties with the deterrence theory aside, ${ }^{206}$ by holding a party liable for their negligence, courts can inspire deterrence of similar future behavior and thereby construct a

201. See generally Conflict of Interest, BLACK's LAW DiCTIONARY (10th ed. 2014) (“A real or seeming incompatibility between one's private interests and one's public or fiduciary duties.").

202. See MAYHEW, supra note 199. Citing this source assumes the Indiana General Assembly behaves like the American Congress.

203. See generally id. Consensus building, vetoes, pork-barrel amendments, and financing all stand as prime examples.

204. Robinson v. Glass, 94 Ind. 211, 212 (1884) (“A man who can read and does not read an instrument which he signs is, as a general rule, guilty of negligence, and so he is, if, being unable to read, he neglects to exercise ordinary prudence in requiring the instrument to be read to him."); see also Stewart v. Cleveland, C., C. \& S. L. R. Co., 52 N.E. 89, 90 (Ind. Ct. App. 1898) (describing the failure to read contracts as deliberate ignorance and refusing to let a party avail themselves of it); Miller v. Powers, 21 N.E. 455, 458 (Ind. 1889) (referring to the failure to read contracts as "blind confidence").

205. See e.g., 28 N.E.3d 333.

206. Compare Furman v. Georgia, 408 U.S. 238, 343 (1972) (“Our jurisprudence has always accepted deterrence in general . . .."), and Samuel J. Rascoff, Counterterrorism and New Deterrence, 89 N.Y.U. L. ReV. 830, 883, with Paul H. Robinson \& John M. Darley, The Role of Deterrence in the Formulation of Criminal Law Rules: At Its Worst When Doing Its Best, 91 GEO. L.J. 949, 1001 (2003), and Dan M. Kahan, The Secret Ambition of Deterrence, 113 HARV. L. REV. 413, 497 (1999). 
government less likely to engage in said behavior. ${ }^{207}$ Thus, the threat of being held accountable and potentially losing one's job and livelihood could potentially urge government workers to take more careful steps at work, such as carefully reading the terms of their contract, although studies on the threat of termination have had mixed results as far as improved productivity or quality. ${ }^{208}$

\section{B. More Efficient Governance}

First, determining the enforceability of an indemnity agreement can, like most litigation, be a long and costly process. Rather than be boiled down in claims for implied indemnification and numerous hearings to determine who must indemnify whom, an express agreement brings predictability and eliminates such drawn out disputes, saving State time and resources. ${ }^{209}$ In addition to saving the State resources, it would clear more space on court dockets and allow trial courts to attend to more pressing matters.

Second, these agreements would afford government contracts more flexibility in cost and risk exchange (for example: a higher rate for no indemnification as opposed to a lower rate but with indemnification) and would allow more options for the government to seek, depending on its financial circumstances. ${ }^{210}$ Most simply, the State would have more alternatives to bargain for and with, which could allow agencies short on funds to negotiate a lower rate by signing an indemnity agreement. ${ }^{211}$ Such flexibility would also allow the State reduce economic waste - saving much needed state resources. ${ }^{212}$ In short then, these agreements would allow the State to know its obligations and avoid draining its resources in court while also giving the State the flexibility to match its existing

207. See Jeremy Bentham, An Introduction to the Principles of Morals and LEGISLATION (Oxford: Clarendon Press 1907) (1780), http://www.econlib.org/library/Bentham/ bnthPML.html [http://perma.cc/5LKF-CUJH].

208. See Al Szymanski, Productivity Growth and Capitalist Stagnation, 48 SCI. \& Soc'y 295, 297-301 (1984) (Positing that the increase of social welfare programs (and thus weakening of the disincentive of losing one's job) has not caused a decline in productivity); Gustav Wickström \& Tom Bendix, The "Hawthorne Effect"-What Did the Original Hawthorne Studies Actually Show?, 26 SCANDINAVIAN J. WORK, ENV'T \& HEALTH 363, 365 (2000) (finding an increase in productivity when threat of termination was higher); but cf. Ulla Kinnunen et al., Organizational Antecedents and Outcomes of Job Insecurity: A Longitudinal Study in Three Organizations in Finland, 21 J. ORGANIZATIONAL BEHAV. 443, 445 (2000) (suggesting protracted feelings of job insecurity could potentially lead to "rigidity," and "adverse effects on perceived performance").

209. Daugherty, supra note 126 , at 578.

210. It is common sense that the State would have more options for negotiating contracts if it could choose between indemnification or not. The idea that having more flexibility in a negotiation — allowing parties to better account for what they need — reduces waste and maximizes the potential of any given contract. See Feng Cheng et al., Flexible Supply Contracts via Options 2-3 (Nov. 2003), http://www.columbia.edu/ yao/flexnewrev.pdf[https://perma.cc/M8EQ-6FRM].

211. See id.

212. See id. 
realities with a dynamic marketplace.

\section{Reduction in Pecuniary and Temporal Waste in the Private Sector}

Just as the uncertainty of an indemnity provision can tie up state funds, it can also impede assets in the private sector. Rather than needing to worry and set aside contingency funds for the realistic chance that their agreement with the State might get thrown aside, private entities would be more certain as to their future obligations and be able to more appropriately allocate their resources, thus reducing economic waste. ${ }^{213}$ In addition to avoiding the loss of pecuniary resources, allowing these agreements could save valuable time and effort. Creating the predictability of knowing the maximum extent of one's own financial liability avoids a "chilling effect" 214 on larger corporations and their upper management. ${ }^{215}$ This allows them to operate more effectively and helps avoid unbridled drops in stock and production, ${ }^{216}$ although some commentators have described the benefit of these agreements more as retaining the services of strong upper management. ${ }^{217}$ Either way, allowing the private sector to utilize these deals with the State could very easily lead to a reduction of waste, both pecuniary and temporal.

\section{CONCLUSION}

In John Milton's eminent Paradise Lost, he sets forth to explain the events surrounding the original sin of man and man's expulsion from Paradise (The Garden of Eden). ${ }^{218}$ Although the title of the book leads one to believe that it is

213. Blake D. Morant, Contracts Limiting Liability: A Paradox with Tacit Solutions, 69 TuL. L. Rev. 715, 728 n.59 (1995); see also Nick Kangles et al., Risk Allocation Provisions in Energy Industry Agreements: Are We Getting It Right?, 49 AlBERTA L. ReV. 339, 347-48 (2012) (noting such agreements allow for parties to reduce wasteful spending in purchasing "redundant insurance coverage" as well as ballooning costs in compelling indemnification, despite the agreement).

214. Olson, supra note 126, at 1039. As understood by Olson, a corporate chilling effect is an apprehension towards otherwise prudent risks, on the part of management, because of uncertainty in some regard. In this context, it is an impediment to otherwise natural and necessary decision making.

215. Id.; see also John Power, Show Me the Money: The Thompson Memo, Stein, and an Employee's Right to the Advancement of Legal Fees Under the McNulty Memo, 64 WASH. \& LEE L. REV. 1205, 1210 (2007).

216. Olson, supra note 126, at 1039; see also Power, supra note 215.

217. Michael J. Dougherty, Note, Are You Covered? Vonfeldt v. Stifel Financial Corporation: Indemnification of Extra-Corporate Personnel Under Delaware Law, 61 U. PITT. L. REV. 527, 531 n. 19 (2000) (noting the view of certainty of risk as a "benefit" is a fallacy because "a successful defense against a suit in the right of the corporation can rarely if ever be of direct 'benefit' to the corporation. Rather, the benefits of indemnification to the corporation lay in obtaining and retaining the director's services").

218. John Milton, PARAdise Lost (Christopher Ricks ed., Penguin Books 2003) (1667). For further reference into the Scripture from which Milton builds his work, see Genesis 3 (New King 
a reference to a single fall - that of mankind - the title actually references two falls: the expulsion of man from the Garden of Eden and Satan's fall from Heaven. ${ }^{219}$ In analyzing the two falls, God remarks that the two are distinguishable in that man was tricked into his fall while Satan fell by his own conscious decision. ${ }^{220}$ As such, man was less culpable and deserving of grace while Satan and his cohort were deserving of everlasting doom for throwing off paradise by their own free will. ${ }^{221}$

Though almost half a millennium old, Milton's words hold weight on the subject of this Note. The State has broad contracting powers, but these powers, once used to enter into a contract-even be it Faustian in nature-eject Indiana from the crest of Mount Olympus, from paradise itself, and oblige the normally untouchable entity to submit to the same laws that they create for their citizens. Like Satan, the State must come to grips with the fact that immunity, like Heaven, once freely relinquished, cannot be retaken. Unlike in Paradise Lost, however, the loss of paradise need not necessarily be detrimental. Express indemnity by the State can benefit both Indiana and its citizens by providing more contracting options, a stronger incentive for closer administration of State dealings, and better allocation of various resources. Though paradise might be lost, optimism need not be.

James); Ezekiel 28:12-19 (New International Version); Isaiah 14 (New International Version).

219. Milton, supra note 218. Framed as a rebellion with clear parallels to the three English Civil Wars of the prior decades (1642-1646 C.E., 1648-1649 C.E., 1649-1651 C.E.), Satan is the ironic protagonist who rebels against a "tyrannical" God, loses, and is consequently expelled from Heaven. As a salve upon his wounds and those of his cohort, he famously utters, "[b]etter to reign in Hell, than serve in Heav'n." Id. at 9.

220. Id. at 55. The passage is particularly worthy and deserving of reference: "He and his faithless progeny: whose fault? Whose but his own? Ingrate, he had of me All he could have; I made him just and right, Sufficient to have stood, though free to fall."

221. Id. 